\title{
電気集じん装置における再飛散現象に対する界面活性剂添加の効果
}

\author{
（学生員）瑞慶覧 章朝（武蔵工大）（学生員）神代 渉 （武蔵工大） \\ （学生員）川田 吉弘（武蔵工大）（正員）江原 由泰（武蔵工大） \\ （正員）伊藤 泰郎（武蔵工大）（正員）高橋 武男 (富士電機) \\ （非会員）川上 一美 (富士電機) (正員) 高松 武史 (富士電機)
}

\section{EFFECT OF SURFACTANT ON RE-ENTRAINMENT PHENOMENA IN AN ELECTROSTATIC PRECIPITATOR}

Akinori Zukeran, Student member, Wataru Jindai, Student member, Yoshihiro Kawada, Student member, Yoshiyasu Ehara, Member, Tairo Ito, Member (Musashi Institute of Technology)

Takeo Takahashi, Member, Hitomi Kawakami, Non-member, Takeshi Takamatsu, Member (Fuji Electric Co., Ltd.)

The collection efficiency for the particle larger than $1 \mu \mathrm{m}$ decreases due to the re-entrainment on an electrostatic precipitator (ESP) for carbon particles. The re-entrainment means that particles on collecting electrodes refly to gas flow. The re-entrainment may be prevented by increasing the adhesive force between particles and collecting electrodes.

In this work, we have investigated the prevention of re-entrainment by spraying water with surfactant into the gas flow. Diesel exhaust particles were used as particulate matter for the experiments. The particle concentration was measured using a scanning electron microscope which is able to count the particle lager than $0.01 \mu \mathrm{m}$. As a result, collection efficiency was improved by spraying water with surfactant into ESP. The results indicate that re-entrainment and particle agglomeration on collecting electrode are prevented.

キーワード：電気集じん装置，再飛散現象，集じん率，界面活性剤，ディーゼルエンジン排気ガス

\section{1.はじめに}

大気污染物質の中で, 浮遊粒子に対する対策として様々 な集じん装置が用いられている。なかでも電気集じん装置 （ESP）は，他の集じん装置と比心゙，微粒子の捕集が容易 であり，压力損失が小さく，消費電力も小さい。このため， 家庭用の空気清浄機から大規模な工業用まで幅広く利用さ れている。

一般に ESP の問題は，帯電理論上サブミクロン粒子の集 じん率が低いことである。これに対して，凝集装置の研究 が多く行われている(1)-(3)。

一方, ESP の性能は, 処理対象粒子の性状によって大き く左右される。特に，カーボンブラック等の低抵抗ダスト を処理する場合，再飛散現象による集じん率の低下が問題 となる ${ }^{(4)}$ 。再飛散現象は，集じん電極上に集じんされた粒 子が気流等 ${ }^{(6)(3)}$ の影響のため, 再び気流中へ飛散する現象で ある。再飛散粒子の多くは，集じん電極上における極板凝 集粒子(8)であり，再飛散による集じん率の低下は，特に粒 径 $1 \mu \mathrm{m}$ 以上の大粒径において顕著である(1)5(1)。また, 再飛 散粒子は再飛散時の集じん電極と同極性の帯電粒子であ $ろ^{(1)(5)(9))}$

再飛散現象が起こることによる集じん率低下の対策とし

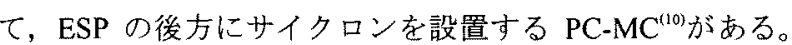
この方法は，本来，凝集装置として開発されたが，再飛散 による大粒径粒子の集じん率低下对策としても有効な手段 である。しかし，装置の大型化，高級化および既存の ESP への付加が困難である。一方，ガス中への水分等の添加 ${ }^{(5)}$ も有効であるといわれている。この方法は装置の大型化が 抑えられ，既存のESP の付加も可能である。また，凝集 効果もあり，サブミクロン粒子の集じん率向上という面に おいても有効な手段の一つである(5)。しかし，再飛散防止 に関寸る研究は極めて少なく，再飛散抑制メカ二ズムに関 する具体的な検討はほとんど見あたらない。

著者らは，ディーゼルェンジン排気ガス中微粒子 (DEP) の集じんに㧍ける再飛散防止に対して，水分の付 着力（液架橋力）に着目し，ガス中への純水噴霧を検討し

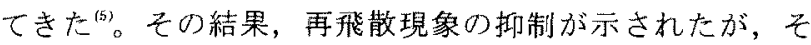
の効果は理論効率に比べ未だ十分ではなかった。この原因 として，DEP はその主成分が疎水性のカーボンであること が挙げられる。

本研究では疎水性の粒子と水分との親和力の增加および, 集じん電極上での洏れ性の向上を目的とし，界面活性剤水 溶液の噴霧を試みた。粒子濃度の測定には，粒径 $0.01 \mu \mathrm{m}$ 以上の測定が可能な電子顕微鏡（SEM）法を用いた。再飛 
散抑制効果，集じん電極上の粒径分布および粒子の形状係 数を測定し，界面活性剤水溶液噴霧による再飛散抑制入力 シズムを検討した。ただし，実験装置は実用機ではなく， 再飛散の発生および確認が容易な実験用 ESPとした。

\section{2. 実験装置および方法}

く2. 1 実験装置概要実験装置概略を図1に示す。サ ンプルガスであるディーゼルエンジン排気ガスは，分流器 により濃度が調整され，混合槽で大気と希釈混合される。 さらに，ブースタファンによってダクト内に送り込まれ， 吸引ファンによってESP を通過し処理されダクト外に排出 される。純水，界面活性剤水溶液を吸気口2の位置においで， 超音波加湿器（ウェットマスター（株）製，ENS30U）に よりガス中へ噴霧した。噴霧水分量は $8.75 \mathrm{l} / \mathrm{h}$ とした。ダ クト内の処理流速は，吸引ファンの回転数によって制御で き $7 \mathrm{~m} / \mathrm{s}$ とした。以下，処理ガスへ水分噴霧を行わない場合， 純水噴霧の場合, 界面活性剂水溶液の噴霧の場合を, それ ぞれ，乾式 ESP，湿式 ESP，界面活性剂噴霧時と呼ぶ。界 面活性剂は，非イオン系である以下の4種類を用いた。

Type A:ポリオキシェチレンノニルフェニルエーテル

Type B:ポリオキシエチレンラウリルエーテル

Type C:ポリオキシェチレンジスチレン化フェノールエーテル Type D:ポリオキシェチレントリベンジルフェノールェーテル

以上の4種類の親油性（HLB 值）と臨界ミセル濃度時の表 面張力を表 1 亿示す。実験に用いた界面活性剂は非イオン 系であり，HLB 值および表面張力以外の性質はおおよそ等 しい。

表1 HLB値と表面張力 $\left(10^{-5} \mathrm{~N} / \mathrm{cm}\right)$

Table 1. Value of HLB and surface tension $\left(10^{-5} \mathrm{~N} / \mathrm{cm}\right)$

\begin{tabular}{|c|c|c|c|c|}
\hline & Type A & Type B & Type C & Type D \\
\hline HLB 值 & 12.4 & 16.9 & 12.8 & 13.2 \\
\hline 表面張力 & 33.5 & 40.0 & 43.5 & 49.7 \\
\hline
\end{tabular}

\section{$<2.2>$ 電気集じん装置の電極構成本研究で用いた} ESP は帯電部と集じん部で構成される2段式 ESP である。 各電極の配置図と粒子サンプリング位置を図 2 に示す。帯電 部は直径 $0.26 \mathrm{~mm}$ のタングステン製の高電圧印加用線電極 とアルミニウム製の接地平板電極で構成されており，ガス 流方向に3段, 計15の帯電部を持っている(1)。集じん部は高 電圧印加用平板電極と接地平板電極が $6 \mathrm{~mm}$ 間隔で交互に並 んだ構造をしており，合計42の集じん部を持っているは。 带電部㧍よび集じん部における印加電圧は，直流正極性11 $\mathrm{kV} ， 5.5 \mathrm{kV}$ とした。すなわち，帯電部における正極性コ口 ナ放電によって正に帯電した粒子は，集じん部における接 地平板電極上に集じんされる。

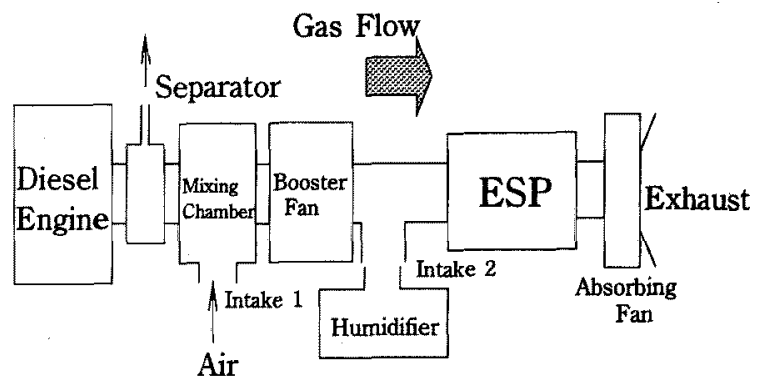

図1 実験装置概略

Fig.I Schematic experimental apparatus

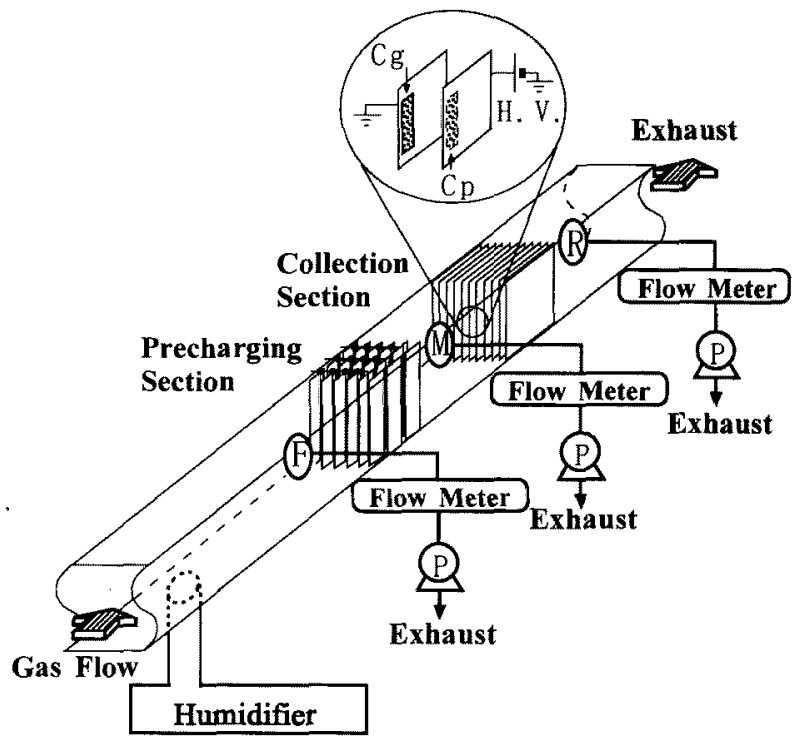

図2 電極配置と粒子サンプリング位置

Fig. 2 Arrangement of sections and particle sampling locations

〈2. 3 >粒子のサンプリング 粒子濃度の测定には SEM 法を用いた 定器では困難なナノメータ粒子まで計測が可能である。粒 子濃度は，空間粒子および集じん粒子に関して測定した。 空間粒子のサンプリングは，図2に示した ESP の前後にお いてダクト中央にメンブレンフィルタ（Coster Sientific Corporation, ニュークリポア, 孔径 $0.015 \mu \mathrm{m}$ ) を設置し, ポンプを通して一定時閒吸引することでフィルタ上に空間 粒子を付着させて行った。ポンプの吸引流量は $0.15 \mathrm{l} / \mathrm{min}$ とした。

集じん電極上に捕集された粒子のサンプリングは，接地 平板電極 $(\mathrm{Cg})$, 高電圧印加用平板電極 $(\mathrm{Cp})$ 上にアルミ箔を 貼り付け，電極に電圧を印加することにより粒子を付着さ せた。

く2.4〉粒子濃度の測定サンプリングした試料を真 空蒸着器によって白金パラジウムを蒸着し SEM（S-4100, （株）日立製作所）によって粒子の拡大画像を得た。さら 

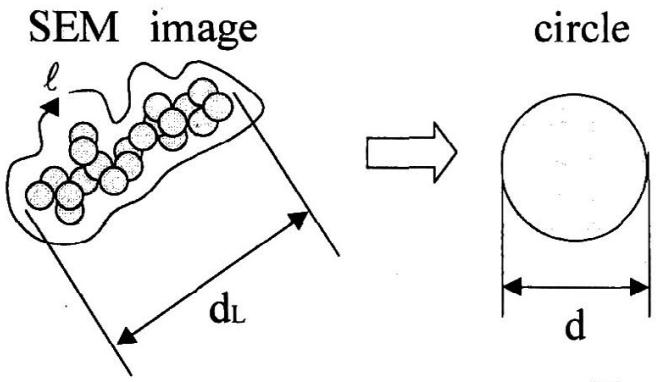

Area : $\mathrm{S}$

$$
d=2 \sqrt{\frac{S}{\pi}}
$$

図3 面積等価円直径の算出

Fig. 3 Calculation of particle diameter

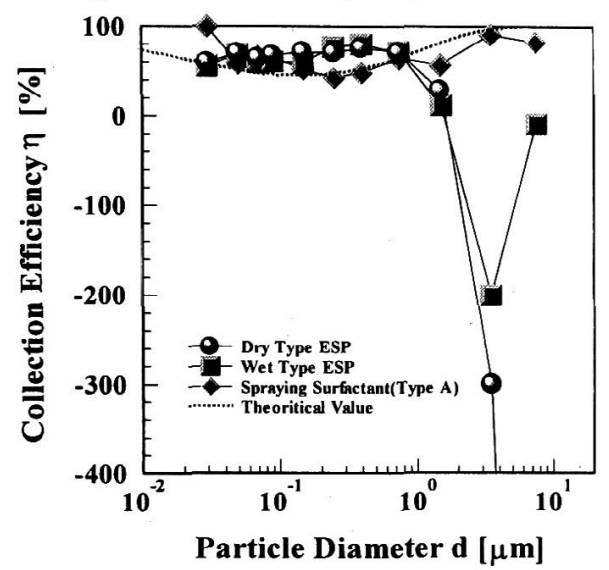

図4各条件における集じん率の粒径特性

Fig.4 Collection efficiency as a function of particle diameter for various conditions

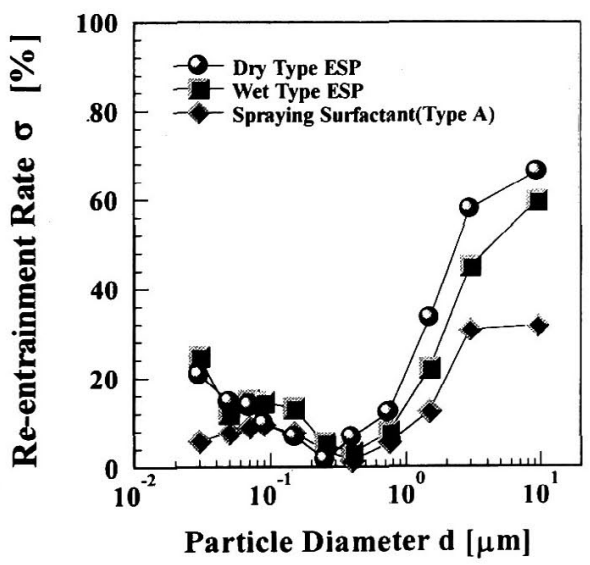

図5 各条件における再飛散率の粒径特性

Fig. 5 Re-enrainment rate as a function of particle diameter for

に, SEM で得た画像を画像処理装置（LUZEX III，（株） ニレコ）によって二值化処理し, 図3に示すように面積等価 円直径 $\mathrm{d}$, 粒子最大長 $\mathrm{d}$, 周囲長 $\ell$ を測定した。各測定值 より, 粒径分布および粒子の形状係数を求めた。粒子の粒 径分布から集じん率を次式で算出した。

$$
\text { 集じん率 }=\left(1-\frac{\text { 流出側の粒子濃度 }}{\text { 流入側の粒子濃度 }}\right) \times 100 \quad[\%]
$$

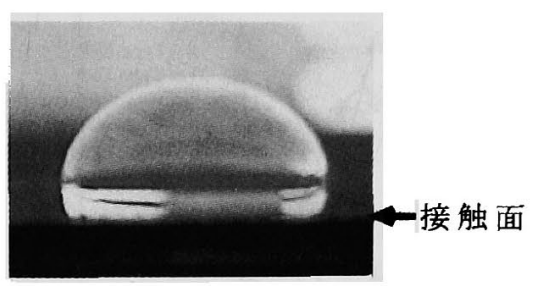

図6 カーボンダスト上の水滴（純水）の状態

Fig. 6 Drop condition of pure water on carbon dust

すなわち，集じん率が正の值の時には流入側に対する流出 側の粒子濃度の減少, 負の值の時には增加を意味する。

\section{3. 実験結果および検討}

く3.1>集じん率の粒径特性各条件における集じん率 の粒径特性を図4に示す。図中には本実験条件下の Deutsch の理論式(11)による計算結果を示してある。理論的には粒径 約 $0.2 \mu \mathrm{m}$ を極小值として粒径が大きくなるに従い, 集じん 率は向上する。これに対し, 乾式 ESP において, 再飛散現 象により粒径 $1 \mu \mathrm{m}$ 以上の大粒径粒子の集じん率が低下して

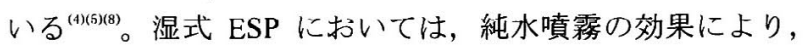
大粒径粒子の集じん率は向上する(5)が，理論值よりも低い 值を示している。一方, 界面活性剤噴霧時においては, 大 粒径粒子の集じん率は飛躍的に向上している。このことは 界面活性剂が，再飛散を抑制していることを示唆している。

〈3. 2〉再飛散抑制効果 二段式 ESP の集じん部におけ る再飛散粒子の多くは, 再飛散時の電極と対向した電極板

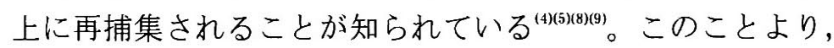
次式によって再飛散率を定義する

$$
\text { 再飛散率 }=\left(\frac{\text { 正極性側の粒子数 }}{\text { 接地側と正極性側の粒子数の和 }}\right) \times 100[\%]
$$

各条件における再飛散率の粒径特性を図5に示す。粒径 1 $\mu \mathrm{m}$ 以下の微粒子では, 実験条件による再飛散率に差は見 られない。しかし，大粒径において乾式，湿式，界面活性 剤噴霧時の順に, 再飛散率は低下している。このことは, 界面活性剂水溶液噴霧による再飛散抑制の効果により，大 粒径粒子の集じん率が向上したことを示している。

カーボン粒子が堆積した電極上に滴下した純水の水滴の 状態を図6に示す。純水の接触角は約144度であり, カーボ ン粒子が疎水性であることが明瞭である。これに対し，界 面活性剂水溶液とカーボンの接触角は0度であった。これは 界面活性剂水溶液を噴霧することで，カーボン粒子の濡れ 性が著しく向上することを示している。すなわち，再飛散 の抑制効果は, 濡れ性の向上に起因していると見ることが できる。

再飛散抑制効果のもう一つの要因として, 粒子形状に着 目し検討する。粒子形状を評価するため, 粒子形状係数 $\alpha_{1}$ および $\alpha_{2}$ 次式で定義する。 


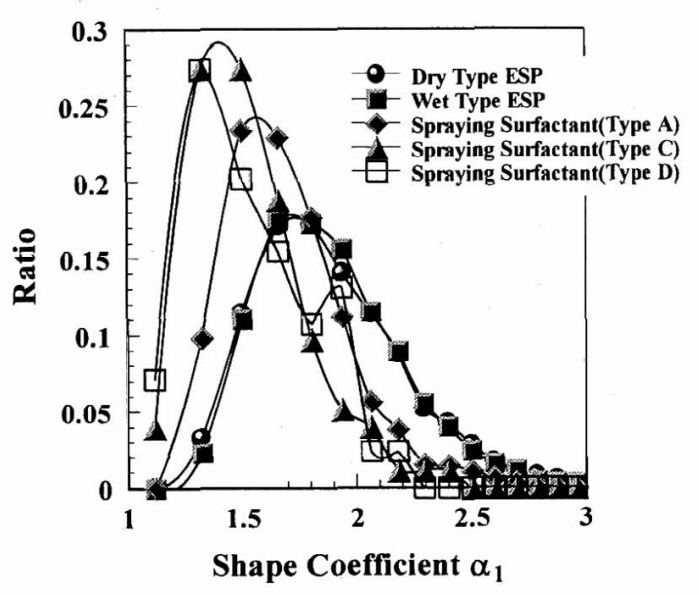

a) $\alpha_{1}$

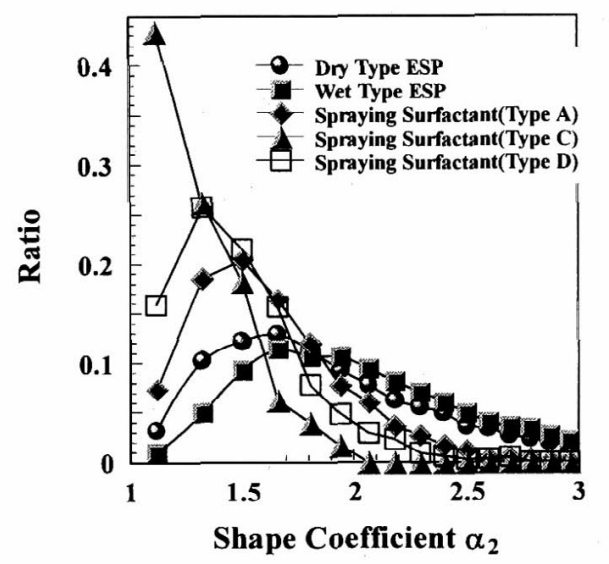

b) $\alpha_{2}$

図7 $\alpha_{1}, \alpha_{2}$ の形状係数分布（粒径1. $6 \mu \mathrm{m}$ 以上)

Fig.7 Shape coefficient distribution of $\alpha_{1}$ and $\alpha_{2}(\mathrm{~d}>1.6 \mu \mathrm{m})$

$$
\begin{aligned}
& a_{1}=\frac{d_{L}}{d} \\
& a_{2}=\frac{\iota}{\pi d}
\end{aligned}
$$

図3に示すように， $\alpha_{1}$ は粒子の最大長と面積等価円直径の比 であり， $\alpha_{1}=1$ のき真円，1より大きいほど細長い粒子であ ることを意味する。また， $\alpha_{2}$ は粒子の周囲長と面積等価円 の周囲長の比であり， $\alpha=1$ のとき真円， 1 より大きくなるほ ど粒子表面の凹凸が多いことを意味する。帯電粒子は集じ ん部接地平板電極上において, 極板凝集により数珠状凝集 粒子を形成する ${ }^{(4)(5)(8)}$ 。すなわち，接地平板電極上における 粒子形状が再飛散現象に大きく影響すると考えられる。接 地平板電極上における粒子形状係数分布を図7に示寸。 $\alpha_{1}$, ａともに, 乾式, 湿式 ESP に比べ, 界面活性剂噴霧時のい ずれの場合も, 分布の最大值の形状係数は小さく, 形状係 数の大きい粒子の比率は低下している。このことは, 界面 活性阂水溶液の噴霧により, 極板凝集粒子が細長い数珠状 から球状に変化したこと,および凝集粒子表面が平滑化し たことを意味する。集じん部接地平板電極上における粒子

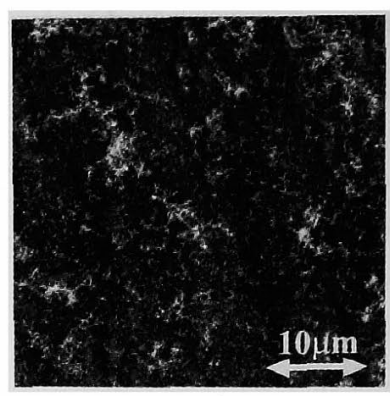

a) 乾式ESP

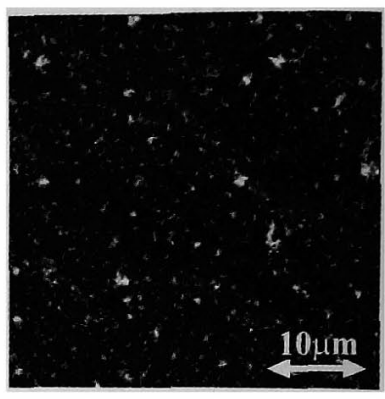

b) 界面活性剂噴霧時
図8 集じん部接地平板電極上粒子のSEM写真（低倍率）

Fig. 8 Typical SEM images on collecting electrode, a)Dry Type ESP, b)Spraying Surfactant (low magnification)

の SEM 写真を図8に示す。a)の乾式 ESP において, 細長い 数珠状の極板凝集粒子が多数観測される。これに対し, b) の界面活性剂噴霧時では, 数珠状粒子がなく, 球状粒子が 観測される。極板凝集粒子の球状化により, 再飛散発生原 因の一つである風力による剥離の影響が縮小する。また, 凝集粒子表面の平滑化により, 粒子と集じん電極間の接触 面積が増大し, van der waals 力および夜架橋力等が増加す る。このため, 再飛散現象が抑制されるといえる。

図7には, 親油性がほぼ等しく表面張力のみが異なる Type A，C，Dの界面活性剂水溶液（表面張力: $33.5 \times 10^{-5} \sim$ $\left.49.7 \times 10^{-5} \mathrm{~N} / \mathrm{cm}\right)$ を処理ガス中へ噴霧した場合の結果も示 してある。形状係数分布は $\alpha_{1}, \alpha_{2}$ いずれも, 界面活性剂の 種類, 寸なわち, 表面張力が大きいほど極大值の形状係数 は小さくなる傾向を示している。このことは，極板凝集粒 子の球状化および粒子表面の平滑化は界面活性剤水溶液の 表面張力に起因していることを意味している。

以上より, 界面活性剤噴霧による次の二つの効果により 再飛散が抑制されていると考えることができた。

1. 濡れ性の向上

2. 極板凝集粒子形状の球状化および平滑化

〈3. 3 極板凝集の抑制界面活性剂水溶液噴霧による 大粒径粒子の集じん率向上の要因として，再飛散抑制効果 が示された。一方，再飛散粒子の多くは，集じん部接地平 板電極上における極板凝集粒子である。界面活性剤水溶液 噴霧による極板凝集現象への影響について検討する。高倍 率における集じん部接地平板電極上粒子の SEM 写真を図9 に示す。乾式 ESP に比べ界面活性剂噴霧時は, 微粒子の状 態で集じん電極上に捕集されており, 図8からも極板凝集に よる大粒径粒子はほとんど存在しない様子が分かる。また， 画像処理により粒径 $1 \mu \mathrm{m}$ 以下の集じん電極上の粒子個数濃 度を測定した結果, 乾式 ESP では約 $1.5 \times 10^{12}$ 個 $/ \mathrm{m}^{2}$, 界面活 性剤噴霧時では約 $4 \times 10^{12}$ 個 $/ \mathrm{m}^{2}$ であった。すなわち, 乾式 ESP に対し, 界面活性剂噴霧時においては, 微粒子が高密 度で存在している。極板凝集抑制モデルを図10に示す。a) の乾式 ESP において, 集じん電極上に低抵抗粒子が捕集さ 


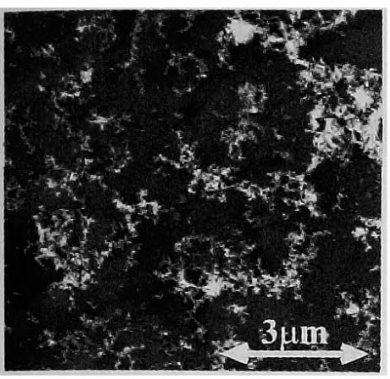

a) 乾式ESP

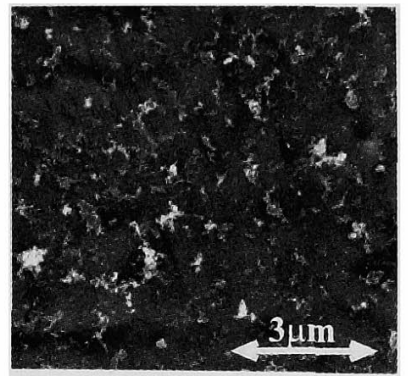

b) 界面活性剂噴霧時
図9 集じん部接地平板電極上粒子のSEM写真 (高倍率)

Fig. 9 Typical SEM images on collecting electrode, a)Dry Type ESP, b)Spraying Surfactant (high magnification)

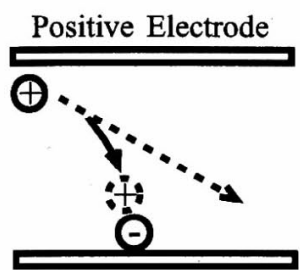

Grounded Electrode

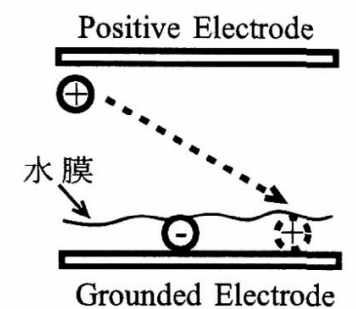

(b) 界面活性剂噴霧時 (a) 乾式ESP

図10 極板凝集抑制モデル

Fig. 10 Model of agglomeration on electrode, a)Dry Type ESP, b)Spraying Surfactant

れた場合，粒子の近傍は電界が強まる。このため，さらに 粒子が捕集されるとき，集じん電極上の粒子と凝集する。 一方, b)の界面活性剂噴霧時においては, 電極表面に水膜 が形成され, 捕集粒子近傍における電界は緩和される。こ のため，極板凝集は抑制される。すなわち，粒子と水分の 濡れ性が重要な要因となる。濡れ性を決定する因子として, 界面活性剂の親油性がある。一般に, 界面活性剤の親油性 を評価する HLB 值は0〜20の值であり，值が小さいほど親 油性が強いことを示す。主に極板凝集粒子が形成される集 じん部接地平板電極上の粒径分布に対する HLB 值の影響を 図11に示す。粒径分布の表現法は様々あるが，本研究に用 いた DEP は粒径が広範囲であることから，一般に多く用い られている対数正規分布 ${ }^{(12)}$ を用いた。すなわち, 縦軸は全 粒子数に対する任意の粒径粒子の比率を測定粒径範囲で規 格化し，対数変換した值となっている。乾式に対し，湿式 ESP における粒径分布はほぼ等しい。しかし, 界面活性剂 噴霧時は大粒径粒子の比率が低下している。ここで, 表面 張力がほぼ等しく親油性の異なる Type B と Type C を比べ ると, HLB 值が小さいほど大粒径粒子の比率は低下してい る。この結果は親油性が高いほど極板凝集現象が抑制され ていることを意味している。

以上より, 界面活性剂水溶液噴霧による大粒径粒子の集 じん率向上に対して，極板凝集現象の抑制効果が示された。

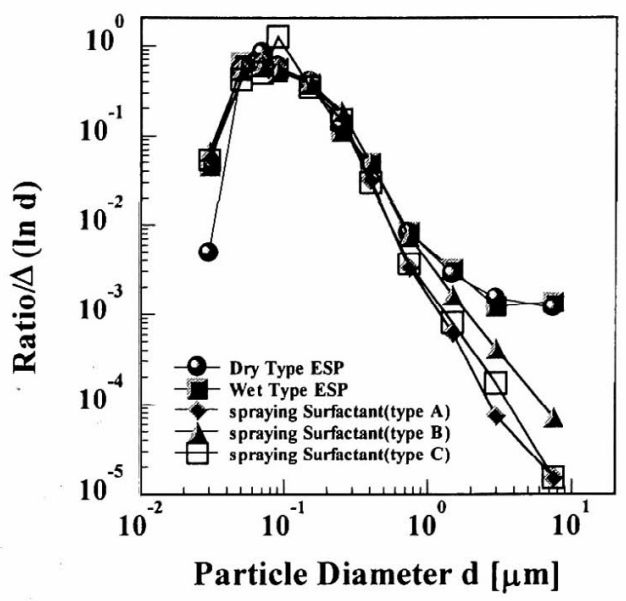

図11 集じん部接地平板電極上の粒径分布に対するHLB值の影響 Fig. 11 Influence of HLB on size distribution on grounded collecting electrode

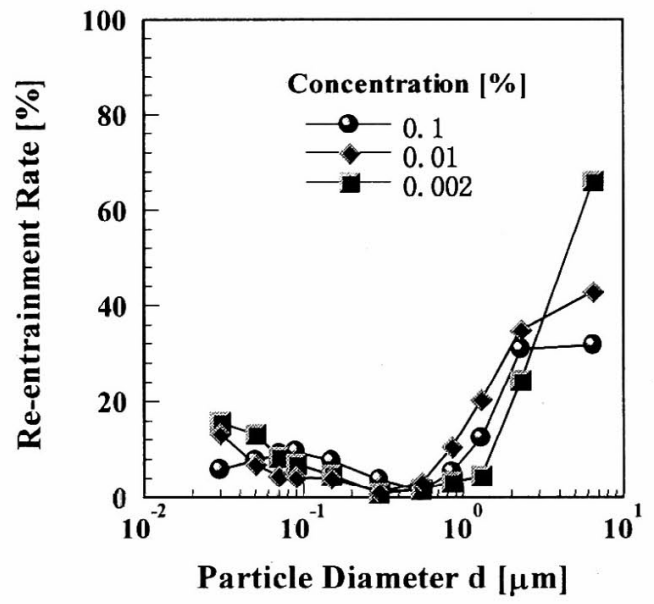

図12 再飛散散率に対する界面活性剂水溶液濃度の影響

Fig. 12 Influence of surfactant concentration on re-entrainment rate

また，この効果は界面活性剂の親油性に依存する。

〈3.4〉濃度の影響ＥSP における再飛散抑制に対して界 面活性剂水溶液噴霧の効果が示された。実用化を考える場 合, 界面活性剂水溶液の濃度が重要となる。再飛散率に対 する界面活性剂水溶液濃度の影響を図 12 に示す。いずれの 濃度においても, 再飛散率はほぼ同様である。本研究に用 いた界面活性剤の臨界ミセル濃度は約 $0.01 \%$ あることを 考慮すると, 界面活性剂水溶液噴霧による再飛散抑制効果 は臨界ミセル濃度程度で良いことが分かる。

\section{4. まとめ}

ESP における再飛散現象を防止するため，処理ガス中へ の界面活性剂水溶液の噴霧を試みた。その結果, 以下のこ とが明らかとなった。

(1) ESPにおいて, 界面活性剂水溶液を処理ガス中へ噴霧す ることで，大粒径粒子の集じん率が著しく向上する。

(2) 界面活性剂水溶液噴霧による再飛散現象の抑制および極 
板凝集現象の抑制の二つの効果により，大粒径粒子の集 じん率は向上する。

(3) 再飛散現象の抑制は, 界面活性剂水溶液噴霧による粒子 間, 粒子一電極間の濡れ性の向上, 極板凝集粒子の球状 化および粒子表面の平滑化の効果に起因する。

（4）極板凝集現象の抑制は, 界面活性剂の親油性に起因し, 親油性が強いほど抑制される。

(5)再飛散現象抑制は臨界ミセル濃度程度で十分である。

本研究の遂行にあたり，尽力を惜しまずにご協力いただ いた佐野規一郎氏に心より感謝致します。

[平成10年5月 8 日受付，平成10年9月 29 日再受付］

\section{文 献}

(1)T. Watanabe, F. Tochikubo, Y. Koizumi, T. Tsuchida, J. Hautanen, E. I. Kauppinen "Submicron particle agglomeration by an electrostatic precipitator", Journal of Electrostatics, 34, pp.367-383(1995)

(2)金沢誠司，足立宜良「二種類荷電法によるサブミクロン粒子の捕集」, 静電気学会誌, 16, 4(1992)

(3)瑞慶覧章朝, 池田泰士, 江原由泰, 伊藤泰郎, 高橋武男, 川上一美, 高松武史，「交流コロナ放電による粉じん粒子の凝集現象」，電気学会 誌 A, 118, 4, pp.367-372(1998)

(4)伊藤泰郎, 久保田強，瑞慶覧章朝，高橋武男，新貝和照，宮本昌広， 吉持達郎「電気集塵機によるサブミクロン粒子の集䴢特性」，電気設 備学会誌, 15, 2, pp.113-120(1995)

(5)瑞慶覧章朝, 伊藤泰郎, 高橋武男, 新貝和照, 川上一美「電気集じん 装置の凝集及び集じん率に及ぼす水分の効果」，電気設備学会誌，16, 12, pp.1288-1296(1996)

(6)J.D.Basset, K.Akutsu, S.Masuda, "A Preliminary of Re-entrainment in an Electrostatic Precipitator", Journal of Electrostatics, 3, pp.311-325(1977)

(7)生三俊哉, 和歌山久男, 増田弘昭「沈着層からの気流による粒子の再 飛散」，化学工学論文集, $12,5, \mathrm{pp} .404-409$ (1994)

(8)A.Zukeran, Y.Ikeda, Y.Ehara, T.Ito, T.Takahashi,H.Kawakami, "Investigation of Tow-Stage Type Electrostatic Precipitator Reentrainment Phenomena under Diesel Flue Gases", Rec. IEEE/IAS Annual Conf., New Orleans, Louisiana, pp.1737-1743(1997)

(9) A.Y.H.Cho, "Contact Charging of Micron-Sized Particles in Intense Electric Fields", Journal of Applied Physics, 35, 9, pp.2561-2564(1964)

(10)諫早典夫, 「静電凝集-遠心集じん方式(PC-MC)の開発研究」, 日立 評論, 49, 11, pp.77-80(1967)

(11)C.Riehle, "Basic and theoretical operation of ESPs", Chapter 3 of Applied Electrostatic Precipitation, K.R.parker, Blackie Academic \& Professional, pp.25 - 88 (1997)

(12)例えば, ウィリアム C・・インズ, 早川一也 監訳, 「ェアロゾル テクノロジー」, 井上書院 (1985)

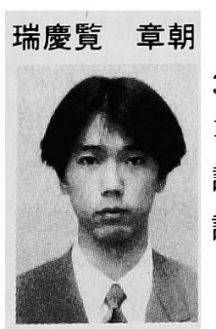

(学生員) 1971年11月15日生まれ。1996年 3 月武蔵工業大学大学院工学研究科電気工学 専攻修士課程修了。同年同大学院博士後期 課程入学。現在に至る。98年電気設備学会 論文賞受賞。

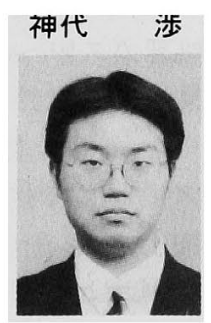

（学生員）1973年11月10日生まれ。1998年 3 月武蔵工業大学大学院工学研究科電気工学 専攻修士課程修了。同年富士電機（株）入 社。現在に至る。

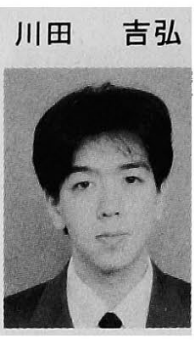

(学生員) 1976年2月16日生まれ。1998年3 月武蔵工業大学電気電子工学科卒業。同年 同大学大学院修士課程入学。現在に至る。

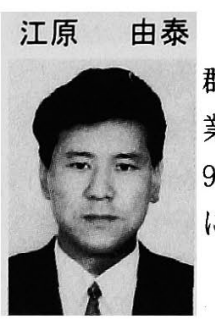

（正員）1956年9月 22 日生まれ。1979年3月 群馬大学合成化学科卒業。同年三恵技研工 業（株）入社。84年武蔵工業大学に勤務。 98年同講師。主に, 高分子絶縁材料の劣化 に関する研究に従事。博士（工学）

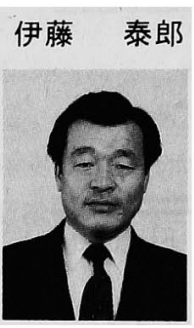

（正員）1935年9月30日生まれ。1960年3月 武蔵工業大学電気工学科卒業。同年武蔵工 業大学に勤務。1982年同教授。80年から81 年米国クラークソン大学客員研究員。86年 電気学会論文賞受賞。98年電気設備学会論 文賞受賞。主に高分子絶縁材料の劣化, 放 電化学反応に関する研究に従事。工学博士。

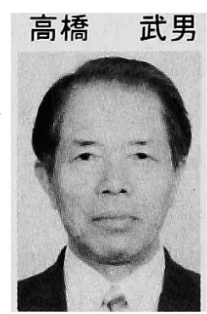

（正員）1939年4月29日生まれ。1963年3月 大阪大学工学部卒業。同年 4 月富士電機 （株）入社。主に電気集じん装置の開発に 従事。98年電気設備学会論文賞受賞。

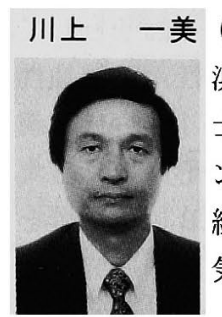

（非会員）1952年4月27日生まれ。1976年横 浜国立大学工学部機械工学科卒業。同年富 士電機（株）入社。主として，水力タービ ンの開発設計, 原子炉の電熱流動の研究を 経て，現在は道路関連設備（トンネルの換 気設備等）の取りまとめ業務に従事。

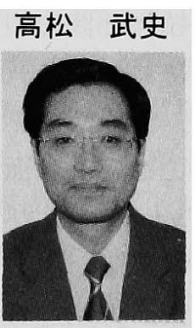

（正員）1956年8月24日生まれ。1979年秋田 大学電気工学科卒業。同年日立プラント建 設（株）入社。火力発電設備の建設, エン ジニアリング業務に従事。91年富士電機 （株）入社。建設付帯設備, クリーンルー ム, 道路関連設備のエンジニアリング業務 に従事。現在, 社会システム事業部企画設 計部企画設計第二課課長。 